\title{
The role of "deprivation" in the conceptualization of social tension in the Ukrainian society
}

\section{Yevhen Siryi}

Taras Shevchenko National University of Kyiv, 4d, Hlushkov ave., Kyiv, 03680, Ukraine

Dr, Professor, Head of the SRC of Sociology Faculty

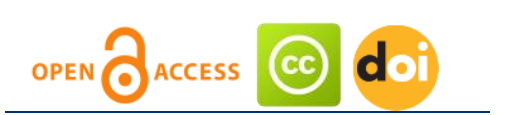

Article history:

Received: November, 2016

1st Revision: November, 2016

Accepted: November, 2016

\section{JEL classification: \\ A14 \\ C31 \\ H55}

DOI:

10.14254/jems.2016.1-1.4

\begin{abstract}
This article attempts to expand interpretational ability of the deprivational paradigm for social tensions (ST). This is due to the conceptual uncertainty, weak presentability and possible underestimation of gnoseological resource of the deprivation theory. This article attempts to construct a semantic core concept of ST using components of T. Gurr's and J. Davis' deprivation theory, theory of frustration by J. Dollard, stress theory by R.K. Merton, and the related theories and concepts that complement and extend the gnoseological potential of deprivation theory. We have performed explicative analysis of deprivation regarding social context, justified and evaluated gnoseological potential of deprivation as a semantic core of conceptualization of social tension. We have analyzed social characteristics of typicality of today's Ukrainian society. We have accentuated the significance and potential of the deprivational paradigm regarding the explanation of social tension, in modern Ukrainian realities that have developed over the past decades.
\end{abstract}

Keywords: social tension, deprivation, frustration, deprivation theory, validity.

\section{Introduction}

Over the last twenty-five years, the system of national socio humanities in the post-Soviet region has allowed us to realize immanence of such phenomenon as social tension. Determined by lack of satisfaction of various needs, it is considered a reflection of the quality properties of the social system. And the fact that it has become an inherent part of modern life, typical to our society as a resource for social change, actualizes its research and study. However, there are several problems in this field of research.

Despite a number of techniques and methodologies to assess the social tension in society, there remains a need to develop such methods, which would allow to conduct integrated evaluation of ST and protest potential in society, as well as the impact of certain factors on the activation of protest mood. This issue is a culmination of several arising problems in this research field. On the

Corresponding author: Yevhen Siryi

E-mail: socio1@mail.ru

This open access article is distributed under a Creative Commons Attribution (CC-BY) 4.0 license. 
other hand, interpretive practices of social tension have certain ambiguity, conceptual approaches and explanations of its various aspects are rather divergent, and there are various problems of methodologies, techniques and search tools. Therefore, the study and measurement of social tension requires finding appropriate and valid "universal" means of perception.

Means of research of social tension are undeveloped in conceptual, methodical and methodological ways. Therefore, social science has to reveal and resolve these theoretical and methodological problems and tasks. There is an urgent need to develop and unify sociological concept, as well as appropriate tools to measure it. Our task is to conceptualize and build a conceptual model of social tension, to justify principles and criteria applied for its interpretation.

\section{Main material}

Previous experience of its measurement demonstrates that without a certain system of elementary theoretical concepts, theoretical and empirical justification of the construction of indicators, the latter cannot be identified in a purely empirical way.

Rising the problem of analysis and understanding of social tension in our society is relatively new to Ukrainian sociology. Since the late 80's - early 90's the society of the former Soviet Union (including Ukraine) has been experiencing a deep systemic crisis, with typical social tension. Its main features were and are: anxiety, dissatisfaction with the existing state of affairs, distrust to the government, etc. Apathy to what was happening, aggression, panic, and even, metaphorically speaking, hope for a miracle - all this became characteristic of our society. The government ignored the fact that while changing from one formation into another, society gets into a marginal position, and not for a short term. There were changes in status, role behavior, the scale of social values. The quality and standard of living, as the most significant factors determining social tension, were chronically low in our country. And the polarization of the society layers (strata) on their financial situation was so sharp, that to this day it constitutes a huge conflict factor.

Ukrainian researches of the post-Soviet period were not ready to produce accurate forecasts and estimate aggravation of social tension. It is believed that before and during the period of perestroika, sociologists, for obvious reasons, were unable to study the phenomenon of social tension in the USSR. Therefore, it is considered that the concept of "tension" in post-Soviet sociology started its development from psychology, which was closer to social "diseases". "Mental tension" usually meant "state of predicting adverse developments" or "state, which follows activities in adverse conditions" (Entsiklopediya, 2015; Meshcheryakov, \& Zinchenko, 2015).

In the subsequent years this term has proved to accurately reflect the state of public relations and mass consciousness, and quickly became a part of scientific, journalistic and everyday vocabulary, reflecting the unfavorable and severe situation. Sociological literature saw it in a different definitional variability, in a specific state of public life, objective and subjective, which is distinguished by social and psychological aggravation. Further, the concept of "social tension" was identified with "conflict", "social crisis" and "instability" - as quite acceptable characteristics of our "sick" society.

Today, several expert assessments of the situation in Ukraine state deepening of the crisis manifestations, the deepest since all years of independence. As the National Institute of Strategic Studies under the President of Ukraine stated in their analytical report "Systemic crisis in Ukraine: preconditions, risks and ways to overcome", the situation in Ukraine can be described as a systemic crisis - a crisis of basic relations in political, legal and socio-economic fields (Zhalilo, Ya., Kononenko, \& Yablonskyi, (2014). As a result, economic depression deepens, the request for social justice remains unsatisfied, there is an abrupt decline in living standards and a distinctive increase of social and political tension in the regions.

Therefore, contemplating on this phenomenon, based on the analysis of relevant scientific sources, it can be stated that the investigation of social tension has formed several traditions of its understanding. In the Western countries, this tradition has been developed though the prism of social well-being of "healthy" society, as opposed to ours.

Historically, since post-war years almost all European countries (societies) have not experienced chronic problems in any area. And their relationship with the institution of state, although sometimes not simple, was yet based on trust. Our tradition of the ST investigation has formed through the prism of an "unhealthy", "sick" society, where tension was a constant attribute. Therefore, its study and methodology was traditionally built following other principles. Social tension has not been investigated much in Ukraine, and foreign experience is not quite close to our reality. This defines a scientific and social problem, to resolve which we have to build and unify an integral conceptual model of social tension in general, and search relevant theoretical interpretations for its integral concept in particular. 
One of the central elements in different explanations of social tension and related protest actions is deprivation, the psycho-social state of a subject, determined by lack of ability to satisfy some of their basic (vital) needs on a sufficient level for a long time. This leads to several moral and psychological deviations in behavior and activity. After the notion of "deprivation" escaped the narrow limits, it was viewed in terms of public life. It was stated that various social modernizations have a negative impact on social behavior.

Scientific literature provides different interpretations of deprivation; it also has various shades of meaning. The theory of deprivation (lat. deprivatio - loss, reduction or withdrawal of the possibility to meet basic psychological or social needs) is not new and "synthetic". Its principles are built on causal connections that are natural and familiar to any of us. Although this notion has a psychological meaning, it acquires certain "social magnetism" in a number of theories that explain the nature of social characteristics related to social tension (conflict, protest, aggression). In the gnoseological perspective of this issue, it is a kind of an interpretive bridge between the psychological state of absence of one's topical needs, and social and individualist reconstruction mechanism of social tension. As a rule, it is connected not just to reduced income, decline in living standards, a real problem of poverty, but also to massive estrangement of citizens from the system of socially meaningful sustainable regulatory connections, political and spiritual frustrations etc., which in the end leads to escalation of social tension.

Deprivation is both a process (psychosocial context) and the result (social context). This notion refers to multifactor problems, and the theory deals with the gap between subjective expectations of different values and the real possibilities to access them (Ozhiganov, 2008). In the context of our social perspective, "deprivation" is used as a social property regarding social problems and factors. Therefore, it occurs in the form of social (in the broad sense, not interactive), spiritual, psycho-cultural identity. That is, it has a lot of 'adjectives' from a number of its possible interpretations, depending on the field of display and the field of application as an explanatory resource.

Social deprivation greatly depends on the degree of how human needs are satisfied. Rather, it arises when satisfaction of needs is impossible or partial. Therefore, its two forms are singled out: absolute, caused by objective deterioration of living conditions, evaluated in terms of quality of life, material well-being, health deterioration, and as inability to meet one's basic needs due to lack of access to material goods and social resources (housing, education, medicine); and relative. Under relative deprivation we understand subjective painful experience of mismatch of value expectations (living conditions and benefits that people believe are allowed and potentially available) and value opportunities (living conditions and benefits that can be obtained in reality). Of course, it is hard to make a clear distinction between absolute and relative deprivation, in this aspect.

One of the major factors affecting instability of public consciousness is the deterioration of life quality. Not only those living in poverty experience the feeling of dissatisfaction today, but also many small and medium businesses. Different people understand and perceive the same social conditions in a different way. As a result, there is different understanding of one's interests even within the same social groups. Insecurity in a particular social, territorial, demographic, professional and other community leads people to a state of irritability, latent aggression. In an infinite combination of factors that form social tension they intertwine and overlap, so we consider it appropriate to apply an integral format of deprivation.

Relative deprivation may be the result of: decrease of real abilities amid growing expectations; decrease of abilities while expectations stay on the same level; growth of expectations while abilities do not change (Garr, 2005). Extrapolating these provisions on a practical level, one can distinguish certain templates, according to which the syndrome of relative deprivation is formed. That is when people are deprived of necessary resources and are unable to support their usual lifestyle; there takes place "deprivation of life standards", often called absolute deprivation. That is when new ideas and values form new standards of life, increased demands and expectations, but in reality people do not have sufficient resources to realize their claims. This leads to a "deprivation of hope". That is when formed expectations and hopes were at first supported by certain opportunities and an adequate level of resources. Later, however, the reality is more and more at odds with the expectations: opportunities and resources slow down their increase, while claims continue to rise. This situation is referred to as "deprivation of the expected pace of change" (Klimov, 2015).

Thus the concept of deprivation indicates dissatisfaction that broad masses of the population experience regarding their status, living conditions, and lack of funds to meet the growing needs. As a result, they start believing that they deserve best, but integrated social conditions are unable to meet their demands, so the only option to get social and political changes is to struggle (often in the form of assault). 
An active factor of tension is conscious willingness of an individual to fight in order to preserve or restore familiar and stable social environment - the immediate social environment, favorability and stability of which is vital. The significance of the immediate social environment and its dependence on macro-social environment (economic, political, legal, cultural and other institutional conditions) makes an individual accept behavior or actions, which imply change, a radical transformation or destruction of the harmful environment, in order to preserve or restore the immediate social environment. This is diagnosed as growth of social tensions.

First of all, social tensions are experienced by those unable to adapt to social changes because of high prices, income decrease, fear to lose their job, status; or because of the "tipping" syndrome, which means one's inability to change their picture of the world, stereotypes, attitudes and beliefs - by those experiencing cognitive dissonance. Obsessions, compelling thoughts and feelings generate relevant experience. Resistance to this process leads to increased internal tension and discomfort that eventually forces to implement these incentives. This form of economic behavior is accompanied by affective tension.

Thus, conscious individual willingness to struggle for preservation or restoration of the familiar and stable social environment is the current factor of tension, which, in its turn, destabilizes the social system. Therefore, the material and social spheres of public life are where tension is concentrated (rather typical in our conditions). But when latent tension transforms into an explicit form, one's main goal becomes to change the political sphere (which is perceived by the major part of society as transformation or destruction of the political structure). Every social group has a threshold level, after which crisis and conflict are likely to occur.

Nowadays, there is a tendency to ignore some forms of social deprivation. However, the concept of deprivation, widely spread since 1970's, is still expanding its gnoseological potential. In modern sociology, the notion of deprivation has acquired a much broader meaning and a whole palette of factors. The concept of deprivation also expands because factors of the basic needs expand, too - not only material, but moral values as well: freedom, rights. The needs are "basic" in a broader sense, as aspects of life important for every human being. This puts them into a category of priority. So we will view this as realization of the primary needs (both material and spiritual). Deprivation was "expanded" by its multidimensional and relative connectedness with other linked phenomena, corresponding concepts, mechanisms of social deviation and destruction. This also is a manifestation of little opportunities, lack of participation in key social activities, a phenomenon of mistrust, various limits of possibilities in life and generation of social exclusion. Proof of this is found in the Russian sources, too (Osipov, 1998; Spesivtseva, 2009). Deprivation is interpreted as one of the integrated, effective forms of loss of social stability, destabilization of the social system. Several forms of deprivation were historically connected with certain alienation from various aspects of social life, social institutes, one's own activities, from those around and the individuals themselves. Alienation is "a state of the individual in the society characterized by social isolation and self-alienation" (Osipov, 1998; Spesivtseva, 2009). Theory of social work derives this concept as "social feeling, when a person realizes not only a gap between expectations and reality, but also lack of social contact, state of social discomfort, accompanied by unusual or negative mental empathy" (Osipov, 1998; Spesivtseva, 2009). Here, we observe a connection with deprivation as well.

In search for the new mechanisms and models of social tension or at least some of its aspects, theories of subjective interpretation acquire more attention as a gnoseological component. While identifying problems of active opportunities of an individual, its status and role characteristics, sociology carried out a research of social consequences, arising from manifestation of egocentric individualism. The scale, intensity and type of relative deprivation determine potential social tensions. The type of social deprivation depends on the group of values that it affects. The concept of scale admits expansion of deprivation on each type of the values: economic, political, social. It is generated by material and value levels, and none of them can be fully interpreted without considering their relation to the others. Although it would be better to distinguish the levels of needs, interests and values. As we can see, this subjective feeling of dissatisfaction with one's realities has acquired more and more factors.

Research of the value transformation of the Ukrainian society in its movement from traditionalism to modernism (the system by R.F. Inglehart) shows that traditional values dominate in the value structure of public consciousness. Current situation in Ukraine is characterized by a growing contradiction between the social needs of the society and the increasing collapse of social services, the destruction of its potential and social infrastructure, intense stratification of the society, increasing the proportion of poor and marginalized population, worsening quality characteristics of the population and social well-being of people, increasing social tensions. Today, Ukrainian society is in a state of uncertainty and its selection of value evolution is rather variable (Siryi, 2014). 
In addition to this, there is another argument. Russian sociologist Y. Levada has investigated the phenomenon of a Soviet individual (homo soveticus), where he stated their typical negative qualities: such as paternalism, suspicion and isolation, cynicism and rising aggression. In his opinion, these negative changes resulted from limitation of social freedoms, and the distorted economic and moral incentives that were implemented by the new government. And although researches have never tried to empirically prove the existence of "homo soveticus", providing only a list of his typical features, they stated that post-Soviet society is a conglomerate of people that belong to a certain "anthropologic type", as opposed to the Western society. This statement is an indirect proof that our society is rather "traditional" (Levada, 2001).

So one of the central elements in many explanatory models of conflicts and related protest action is deprivation, which we understand as a sense of difference between value expectations (benefits and living conditions that people believe they deserve) and value opportunities (benefits and living conditions that people believe they can obtain using available social means) (Garr, 2005).

Thus, deprivation theory, which is developing since the middle of the XX century, is used to analyze and explain social causes and conditions of collective reactions (mobilization, protest, violence, etc.). It binds certain limitations in social and economic life, experienced by groups of people united on stratificational, regional or other cluster basis.

Growing discontent (i.e., subjectively evaluated gap between actual and desired reality) is accompanied by increasing readiness for action, including destructive actions that would help to achieve the goal. This is very likely to unbalance the social system. This problem did not occur much in Western sociology, since it was not typical on the level of massive macro-social processes in Western society. Nevertheless, its theoretical application to the displays of social tensions uncharacteristic for "healthy" society still meets an appropriate level of verification.

\section{Conclusions}

The problem of social deprivation remains understudied. However, our concept has built an integral construct of chronic social deprivation, combining: deprivation theory (T. Gurr, J. Davis) and the related frustration theory (J. Dollard), also the theory of social tension (R.K. Merton). Each of these theories was individually applied to European realities in an attempt to explain origin and development of the processes that are a form or type of social tension. These processes were local and temporary on the background of the common social "security" syndrome ("social satiety"). Sometimes this problem was perceived similar to Weber's understanding sociology and the construction of ideal types. In Ukraine, social problems were and are chronic. That is why it is possible to indicate the search concept of deprivation with a focus on duration or chronicity. However, this can be attributed to an attempt to verify foreign theories in order to explain social tension in the current national context.

This means that deprivation as a kind of reaction is one of the central elements in several explanatory models of conflicts and the related protest actions as ontological characteristics of social tension. This theory is close to many interpretational theses of both tension and the related processes. It is not to be taken as a dogma in the conceptualization of social tension; however, it has sufficient cognitive resources on the latter, as well as a communicative resource, to match other relevant subjectivistic theories.

While developing conceptualization of social tension, we are inclined to the paradigm of deprivation, since all past and present events are in their own way connected with this mechanism of social tension and its factors. At present, that is the most verified point of view. Although it has been proved that there is no clear and obvious connection between orientations and activity, the existence of absolute deprivation and relative deprivation syndrome is not a sufficient, but still a rather significant condition for a collective action.

The latest projections of the development of the current conceptual model of social tension cause emergence, establishment and development of various forms of public protest activity. Therefore, the key aspect of the conceptual model of social tension should be not only deprivation and decline of social well-being, but condition and effectiveness of social connections as well.

\section{Appendix A. Supplementary material}

Supplementary data associated with this article can be found, in the online version, at http://dx.doi.org/10.14254/jems.2016.1-1.4

\section{Funding}

The authors received no direct funding for this research. 


\section{Citation information}

Siryi, Ye. (2016). The role of "deprivation" in the conceptualization of social tension in the Ukrainian society. Economics, Management and Sustainability, 1(1), 42-48. doi:10.14254/jems.2016.1-1.4.

\section{References}

Berkovits, L. (2001). Agressiya: prichiny, posledstviya, kontrol [Aggression: Causes, Consequences and Control]. Spb.: Russia. [in Russian].

Dahrendorf, R. (1959). Class and Class Conflict in Industrial Society. Stanford, Stanford University Press.

Davies, James C. (1962). Toward a theory of revolution. American Sociological Review, 27.

Davies, James C. (1971). When Men Revolt and Why. New York: Free Press.

Entsiklopediya sovremennoy yuridicheskoy psikhologii [Encyclopedia of modern legal psychology]. (2015). Retrieves from: http://www.legal_psychology.academic.ru/425/ [in Russian].

Garr, T. (2005). Pochemu lyudi buntuyut [Why Men Rebel]. SPb.: Piter. [in Russian].

Gurr, T. (1970). Why Men Rebel. Princeton: Princeton University Press. [in Russian].

Klimov, I. (2015). Deprivatsiya. Bol'shaya Rossiyskaya Entsiklopediya [Deprivation. Currency converter]. Retrieved from: http://bigenc.ru/sociology/text/1948445. [in Russian].

Levada, Yu. (2001). "Chelovek sovetskiy": problema rekonstruktsii iskhodnykh formform ["Soviet man": the problem of the reconstruction of the original forms]. Monitoring obshhestvennogo mnenija: jekonomisesie i social'nye peremeny = Monitoring of public opinion: economics and social changes, 2(52), 7-16. [in Russian].

Merton, R. (2006). Sotsial'naya teoriya i sotsial'naya struktura [Social Theory and Social Structure]. Moscow, Russia: AST. [in Russian].

Meshcheryakov, B., \& Zinchenko, V. Bol'shoy psikhologicheskiy slovar [A significant psychological dictionary]. (2015). Retrieves from: http://www.gumer.info/bibliotek_Buks/Psihol/dict/ [in Russian].

Mitrokhin, V.I. (2000). Sushchnost' i kriterii sotsial'noy napryazhennosti [The nature and intensity of social criteria]. Moscow, Russia. [in Russian].

Oberschall, A. (1973). Social Conflict and Social Movements. Englewood Cliffs, Prentice Hall.

Osipov, G. (1998). Sotsiologicheskiy entsiklopedicheskiy slovar [Sociological Encyclopedic Dictionary]. Moscow: INFRA-M NORMA. [in Russian].

Ozhiganov, Ye. (2008). Politicheskaya napryazhennost': imitatsionnoe modelirovanie i rannee preduprezhdenie. [Political tensions: simulation and early warning]. Analiticheskiy vestnik = Analytical bulletin, 9(354), 10-21. [in Russian].

Rumyantseva, T. G. (1994). Ponyatie agressivnosti v sovremennoy zarubezhnoy psikhologii [The concept of aggression in modern foreign psychology]. Moscow. [in Russian].

Shtompka, P. (1996). Sotsiologiya sotsial'nykh izmeneniy [Sociology of social change]. Moscow: Aspekt Prese. [in Russian].

Siryi, Ye. (2014). Transformatsiini zminy tsinnisnoi systemy ukrainskoho suspilstva u systemi koordynat: «tradytsiia - modern» [Transformational change the value system of Ukrainian society in the coordinate system "tradition - modern"]. Visnyk Lvivskoho universytetu. Seriia sotsiolohichna = Bulletin of Lviv University. Series sociological, 7, 3-18. [in Ukrainian].

Siryi, Ye. (2016). Doslidzhennia sotsialnoi napruzhenosti v ukrainskomu transformatsiinomu sotsiumi [The study of social tension in Ukrainian society transformation]. Aktual'ni pitannja, problemi ta perspektivi rozvitku gumanitarnogo znannja u suchasnomu informacijnomu prostori: nacional'nij ta internacional'nij aspekti. Monreal-Rubizhne, 193-196. [in Ukrainian]. 
Smelser, N. (1962). Theory of Collective Behavior. N.Y.: Free Press.

Sotsial'naya rabota: slovar'-spravochnik [Social work: Dictionary Directory]. (1998). Moscow: Kontur.[in Russian].

Spesivtseva, 0. (2009). Sotsial'no-ekonomicheskie izmeneniya kak genezis deprivatsiy [Socioeconomic changes in both the genesis of deprivations]. Vestnik Chelyabinskogo gosudarstvennogo universiteta = Bulletin of the Chelyabinsk State University, 14(152), 84-86 [in Russian].

Sushyi, O.V. (2015). Dynamika politychnykh i psykholohichnykh protsesiv u suchasnii Ukraini [The dynamics of political and psychological processes in modern Ukraine]. Collection of articles "Scientific studies of social and political psychology", 5, 38. [in Ukrainian].

Zhalilo, Ya., Kononenko, K., \& Yablonskyi, V. (2014). Systemna kryza v Ukraini: peredumovy, ryzyky, shliakhy podolannia [Systemic Crisis in Ukraine: preconditions, risks and ways to overcome]. Kyiv, Ukraine: NISD. [in Ukrainian].

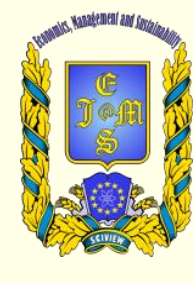

() 2016 Economics, Management and Sustainability. All rights reserved.

This open access article is distributed under a Creative Commons Attribution (CC-BY) 4.0 license.

You are free to:

Share - copy and redistribute the material in any medium or format Adapt - remix, transform, and build upon the material for any purpose, even commercially.

The licensor cannot revoke these freedoms as long as you follow the license terms.

Under the following terms:

Attribution - You must give appropriate credit, provide a link to the license, and indicate if changes were made.

You may do so in any reasonable manner, but not in any way that suggests the licensor endorses you or your use.

No additional restrictions

You may not apply legal terms or technological measures that legally restrict others from doing anything the license permits.

Economics, Management and Sustainability (ISSN: 2520-6303) is published by Scientific Publishing House "CSR", Poland, EU and Scientific Publishing House "SciView", Ukraine

Publishing with JEMS ensures:

- Immediate, universal access to your article on publication

- High visibility and discoverability via the JEMS website

- Rapid publication

- Guaranteed legacy preservation of your article

- Discounts and waivers for authors in developing regions

Submit your manuscript to a JEMS at http://jems.sciview.net or submit.jems@sciview.net 